原著

\title{
北津軽郡の歯牙フッ素症発現地域における 飲料水中フッ素濃度の変動について
}

\author{
松田 和 弘* 飯島洋 一* 田 沢 光 正* \\ 高江 洲義 矩* 久米田俊 英**
}

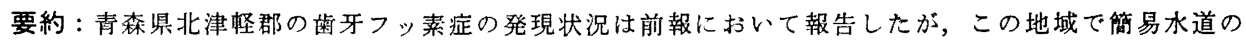
水源として利用される深井戸（ボーリング深度200 300m）について，フッ素㴗度の経時変化を調查し た。

23 水源から毎月 1 回採水した年変化では，4 水源に著しい濩度変動を認めた（恋動倸数: $22 \sim 37 \%) 。$ 1 カ月に 1 回採水して得たフッ素漉度の各月における代表性を検討するため, 変動の大きいものから 1 水源を選んで毎日採水して28日間の月変動を調べた。その結果, 連日不規則な変動を示すことが明らか となり，1カ月に 1 回の採水では採水日によって測定值に大きい影響をうける可能性が示唆された。

これらのことから，生体に対する飲料水中フッ素の影響を検討する場合，断片的な採水によるフッ素 漂度の誤認を避けるだけでなく, 得られる一定期間の平均濃度を適切に解釈するためにも, フッ素浱度 を経時的に測定し，年変動や月変動などををとに変動の概要を把握することが不可欠であると考える。
\end{abstract}

\section{はじめに}

飲料水中フッ素濃度は，歯牙フッ素症 Dental fluorosis を判定する際の条件として，またその症度の軽重 との関連で重要視されてきた。一般にそのフッ素浱度 は，水源がおかれた地理的条件，自然現象あるいは表流 水，浅井戸，深井戸といった形態によって様々に影響を うけて変動している。Dean ら ${ }^{1,2)}$ は，すでに1930年代 の一連の 斑状歯 Mottled enamel 調査のなかで, 飲料 水中フッ素濃度の変動の重要性を指摘している。わが国

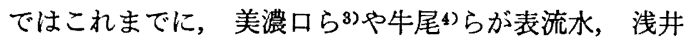
戸を中心にフッ素濃度の変動を調査し, 飲料水中フッ素 が生体におよぼす影響を検討するにあたっては，その経 時的濃度変化に対する注意を喚起している。

著者らが1974年から調査を続けている青森県北津軽郡
の歯牙フッ素症発現地域5)で利用される簡易水道の水源 は，ほとんどのボーリング深度が200〜300m に達する 堀抜きの深井戸であるが，水源によってはフッ素濃度に 著しい変動が認められた。そこで，これらの23水源から 毎月採水したフッ素濃度の年変化と, そのらちとくに変 動の大きい 1 水源から毎日採水した月変化を調查したの で報告する。

\section{方 法}

青森県北津軽郡の板柳町沿川第一小学校区（沿小区） と鶴田町梅沢小学校区（梅小区）で飲用される簡易水道 の23水源を対象とした。水源の概要は前報6のとおりで ある。採水期間は1974年10月から翌年 9 月までの 1 年間 とし，毎月下旬に各水源とも同一蛇口から採水した（沿 小区は 6 月，梅小区は 7 月を除く 11 回)。変動の大きい

* 岩手医科大学歯学部口腔衛生学諥座（主任：高江洲義矩教授）

**岩手医科大学歯学部口腔病理学講座（主任：鈴木鍾美教授）

* Department of Preventive Dentistry, School of Dentistry, Iwate Medical University (Director: Prof. Yoshinori TAKAESU)

* Department of Oral Pathology, School of Dentistry, Iwate Medical University (Director: Prof. Atsumi SUZUKD

昭和53年 2 月 28 日受付 
Table 1 Annual deviation in fluoride content of drinking water. (mg/1)

\begin{tabular}{|c|c|c|c|c|c|c|c|c|}
\hline \multicolumn{9}{|c|}{ Soikawadaiichi primary school district } \\
\hline Source of $w$ & rell & Area & Mean & S.D. & C.V. $(\%)$ & Min. & Max. & Depth of well $(\mathrm{m})$ \\
\hline Soi & 1 & Jokaibashi & 2.96 & 0.65 & 22 & 1.37 & 3.68 & 250 \\
\hline Soi & 2 & Jokaibashi & 3.23 & 0.19 & 6 & 2.71 & 3.51 & 300 \\
\hline Soi & 3 & Oki & 0.38 & 0.02 & 5 & 0.32 & 0.40 & 200 \\
\hline Soi & 4 & Oki & 0.34 & 0.02 & 6 & 0.32 & 0.39 & 100 \\
\hline Soi & 5 & Yugaozeki & 0.60 & 0.17 & 28 & 0.48 & 1.02 & 210 \\
\hline Soi & 6 & Yugaozeki & 0.33 & 0.02 & 6 & 0.31 & 0.37 & 235 \\
\hline Soi & 7 & Yugaozeki & 0.36 & 0.02 & 6 & 0.31 & 0.38 & 270 \\
\hline Soi & 8 & Gorintai & 1.02 & 0.04 & 4 & 0.98 & 1.10 & 300 \\
\hline Soi & 9 & Gorintai & 1.54 & 0.10 & 6 & 1.36 & 1.64 & 230 \\
\hline Soi 1 & 10 & Yugaozeki & 0.31 & 0.01 & 3 & 0.29 & 0.33 & - \\
\hline \multicolumn{9}{|c|}{ Umezawa primary school district } \\
\hline \multicolumn{2}{|c|}{ Source of well } & Area & Mean & S.D. & C.V. $(\%)$ & Min. & Max. & Depth of well $(\mathrm{m})$ \\
\hline Ume & 1 & Serazawa & 1.97 & 0.05 & 3 & 1.90 & 2.06 & 200 \\
\hline Ume & 2 & Serazawa & 0.85 & 0.03 & 4 & 0.82 & 0.90 & 240 \\
\hline Ume & 3 & Serazawa & 1.91 & 0.44 & 23 & 1.46 & 2.61 & 200 \\
\hline Ume & 4 & Serazawa & 0.63 & 0.02 & 3 & 0.59 & 0.66 & 200 \\
\hline Ume & 5 & Yokoyachi & 1.07 & 0.03 & 3 & 1.02 & 1.13 & $250 \sim 300$ \\
\hline Ume & 6 & Yokoyachi & 1.55 & 0.05 & 3 & 1.46 & 1.64 & 150 \\
\hline Ume & 7 & Yokoyachi & 0.91 & 0.03 & 3 & 0.86 & 0.98 & 150 \\
\hline Ume & 8 & Oki & 0.96 & 0.07 & 7 & 0.89 & 1.10 & 180 \\
\hline Ume & 9 & Oki & 0.98 & 0.36 & 37 & 0.50 & 1.27 & 210 \\
\hline Ume & 10 & Oki & 0.92 & 0.07 & 8 & 0.78 & 1.00 & 180 \\
\hline Ume & 11 & Matsukura & 0.83 & 0.04 & 5 & 0.77 & 0.90 & 160 \\
\hline Ume & 12 & Matsukura & 0.95 & 0.04 & 4 & 0.88 & 1.00 & 250 \\
\hline Ume & 13 & Matsukura & 0.93 & 0.03 & 3 & 0.89 & 1.00 & 145 \\
\hline
\end{tabular}

Analysis : 11 times from Oct. 1974 to Sep. 1975.

梅沢小学校区 No. 3 水源（梅 3 ）については，1977年 11月21日から12月18日に至る28日間, 毎日夕方同一蛇口 から採水した。フッ素の定量は, イオン電極法（オリオ ン社製）で行なった。

\section{結果および考察}

沿川第一，梅沢両小学校区の23水源から毎月 1 回採水 した年間フッ素濃度の平均值とばらつきは Table 1 の とおりである。多くの水源の 変動係数 (S.D./Mean) は $5 \%$ 前後を示して，全体として安定している。しかし ながら, 沿 1 , 沿 5 , 梅 3 および梅 9 の 4 水源では, 変 動係数が22 37\%と変動が大きい。とくに沿 1 や梅 3 水 源では，1回だけの採水ではそれぞれ最大 $2.31 \mathrm{mg} / 1$ お よび1.15mg/1 の濃度差を生じることになる。これら 4 水源のボーリング濃度はいずれむ200 300m に達して
いるが，他の水源と比較して変動の大きさと哚度には一 定の関係が認められない。

Fig. 1 の経時変化のグラフからみて，8月に採水した 沿 1 水源の濃度 $1.37 \mathrm{mg} / 1$ は異常值と思われたが，フッ 素に対して相関の高い塩素やナトリウム濃度6) も全期間 を通じてフッ素と同様の変動傾向を示すことから棄却し なかった。仮にその值を重てた場合でも，平均値士標淮 偏差 (変動係数) は $3.11 \pm 0.40 \mathrm{mg} / 1(13 \%)$ ，その範囲は $1.08 \mathrm{mg} / \mathrm{l}$ となり比較的変動が大きい。また, 沿 2 水源 のように変動係数が $6 \%$ でも, 平均值 $(3.23 \mathrm{mg} / \mathrm{l})$ が高 いため範囲が $0.80 \mathrm{mg} / 1$ と注意を要する例もある。この ように, 経時的に濃度変動を調べることは, それによっ て 1 回だけの測定によるフッ素濃度の誤認を避けるだけ でなく, 得られる平均値の意味を解釈するうえで欠かす ベきではないと考える。 


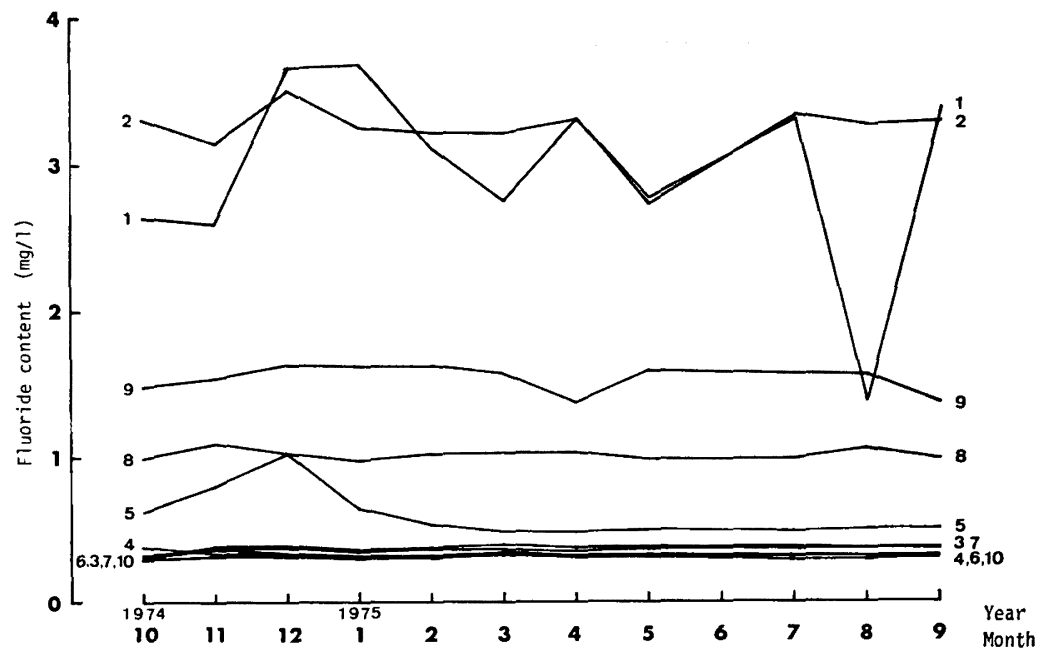

Fig. 1(a) Annual deviation in fluoride content of drinking water from Soikawabaiichi primary school district.

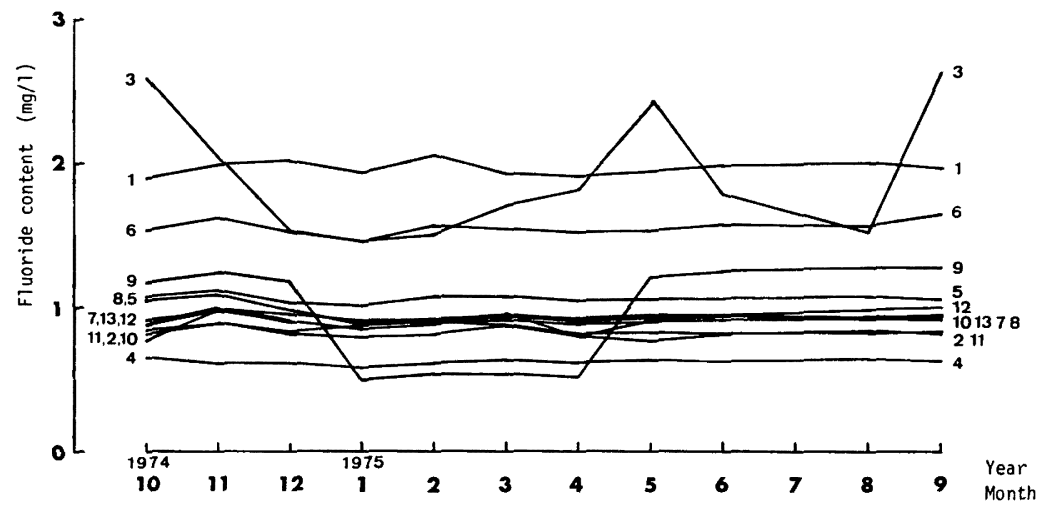

Fig. 1(b) Annual deviation in fluoride content of drinking water from Umezawa primary school district.

Dean らは，歯牙フッ素症の発現と飲料水中フッ素穠 度の関係を検討する場合, 飲料水中フッ素濃度の変動と, 被検者の居住歷（飲水歷）をとくに重要視している。前 者の変動については,さらに同一水源での経時変動1,2)と 水源の変更による浱度変化の例》をあげている。いずれ も検診時に 1 回だけ測定した濃度からは信頼できる結論 をひきだすことが不可能であろうと述べている。たとえ ば, Cororado Springs のように毎月 1 回ずつ 1 年間に わたって測定した值で, 最高, 最低值がそれぞれ $3.0 \mathrm{mg} / \mathrm{l}$, $1.8 \mathrm{mg} / 1$ となっている。そこで, 彼らは調查地域の飲料 水中フッ素濃度として, 毎月 1 回連続12回測定した年平 均值を採用している1。水源の変更は本調査地区にも多 〈みられ(6)，なかには歯牙フッ素症やう蝕の罹患状況か
ら，堀りかえに伴ってフッ素濃度が変化したと推測され るものもある8,9)。

今回調査した水源の多くが示したように，各月の任意 の採水日による 1 年間の測定值が安定している場合，そ の安定性が偶然による確率は極めて少ないと考えられ る。これに対して，前述の 4 水源のよらに大きい変動が みられる場合，各月の 1 回だけの測定値はそれらの月を 代表する浱度とみなすことはできない。従って，Fig. 1 に示した経時変化のパターンは, 実際の変動の一類似 形とみなすことが妥当である。

そこで，今回変動の大きかった水源のなかから梅 3 水 源を選んで，ほぼ 1 カ月にわたり毎日採水して採水日に よるフッ素濃度への影響を検討した。その結果, 平均值 


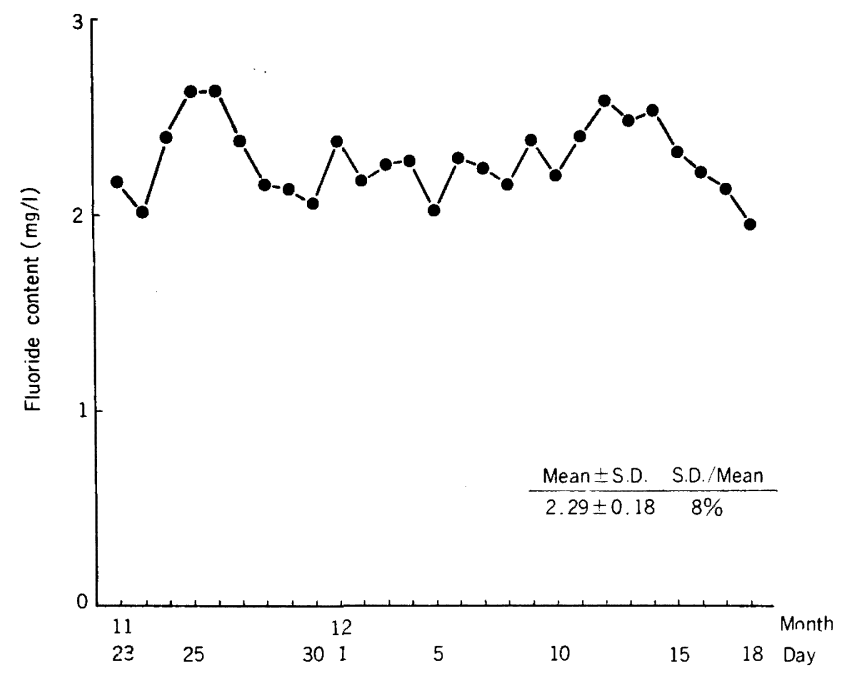

Fig. 2 Monthly deviation in fluoride content of drinking water from the No. 3 source in Umezawa primary school district.

などは $2.29 \pm 0.18 \mathrm{mg} / 1(8 \%)$ を示し，その経過は Fig. 2 のように連日にわたって不規則に変化していることが 明らかとなった。このばらつきは同水源の年変動に比べ て小さいが, この1カ月を例にとっても最高, 最低値が $2.64 \mathrm{mg} / 1,1.97 \mathrm{mg} / 1$ となり, 月に 1 回の採水では最大 $0.67 \mathrm{mg} / 1$ の差を生じることになる。このことから， 1 カ月に 1 回だけ採水する場合, 連日の濃度変動の規模を 把握しておくことが望ましいと考えられる。調查目的に よってはさらに採水時間ごとの日内変動を検討する必要 がある。

牛尾は, 斑状歯（歯牙弗素症）との関連で, 京都府岩 滝地区におけるボーリング深度 $15 \sim 22 \mathrm{~m}$ の陶抜き井戸 4 水源から14力月にわたって $3 \sim 5$ 日ごとに採水して, フッ素濃度の変動を克明に調査している4)。ある水源で は, 調査開始から8.5力月の間は1.32 1.65mg/1 であっ たが，突然 $2.40 \mathrm{mg} / 1$ に急上昇している。しかも，この

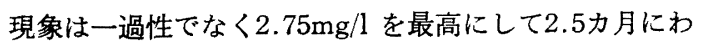
たって $2.40 \mathrm{mg} / 1$ を下まわることがなかった。ほかにも， 測定開始から 3 週間 $1.60 \pm 0.06 \mathrm{mg} / 1$ だった值が， 2.75 $\mathrm{mg} / 1$ に急上昇し, その 3 週間後の $3.40 \mathrm{mg} / 1$ まで漸増を 続けて平均 $3.05 \pm 0.32 \mathrm{mg} / 1$ を示す水源もあった。この ように, 一定期間比較的安定した濃度を維持しながら, 突然変化するタイプもみられる。

近年う蝕予防を目的とした水道水フッ素添加に関連し て $0.5 \mathrm{mg} / 1$ 前後の低濃度レベルのフッ素とう蝕抑制お よび斑状歯発現との関係が注目されている。このなか で,これまでの多くの報告にみられた過去のフッ素濃度
に起因する歯牙フッ素症と, 検診時に測定したフッ素濃 度との時間的ズレを考虑して, 被検者の歯牙石灰化期間 に実測されたフッ素濃度にもとずく歯牙の追跡調査が笠 岡10)などで実施されている。著者らが調査を続けている 北津軽地区でも，1980年以降飲料水中フッ素濃度の実測 值と歯牙フッ素症発現との関係を現在よりも正確に把握 することが可能になる。

フッ素による歯牙の石灰化異常については, エナメル 芽細胞のフッ素に対する感受性が時期的に異ることが示 唆されている11。また牛尾山は, ラットに $100 \mathrm{mg} / 1$ フッ 素を飲料水として 3 日間投与し, 続く 4 日間は無投与と し，これを 3 カ月間くりかえした。その結果，フッ素投 与期間に対応する歯牙の部位に著明な白線が現われたほ かに，無投与時に対応する部位にも体内蓄積されたフッ 素によると考えられる微細な白線を認めたという。

本調査地区の一部の水源にみられるように連日にわた ってフッ素濃度が変動する場合, 歯牙ならびに生体緒組 織におよぼすフッ素の影響は, その平均值的な一定期間 維持する浱度レベルと, 一過性ではあるが短期間に不規 則にくりかえす高濃度フッ素とどのように関連するのか 興味深、問題である。また, 本調查地区の梅 9 水源 (Fig.

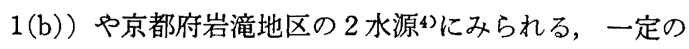
フッ素浱度レベルが 数週間から 月単位で 交代する現象 が，歯牙の石灰化期間の一部分にあたる場合にも同様の 問題が考えられる。

なお， 約 $3 \mathrm{mg} / 1$ のフッ素を含有していた沿川第一小 学校区の No. 1 および No. 2 の 2 水源は1977年の 1 月 
に廃止されて, 新たに $0.6 \mathrm{mg} / 1$ 前後の水源が堀井され た。また，梅沢小学校区では1976年 8 月から鶴田町上水 道の給水が 開始され，上水道加入者が漸次增加してい る。この水源は 2 本の堀拔き井戸で，ストレーナーは $150 \sim 200 \mathrm{~m}$ である。1977年 1 月と 5 月に採水した 源水 のフッ素浱度は $0.63 \sim 0.74 \mathrm{mg} / 1$ であった。

梅沢小学校区 No. 3 水源の採水にあたってご協力を いただいた同校の児童高橋恵美子嫬と，そのご指導にあ たられた同校渡辺順子先生に感謝いたします。

\section{文献}

1) Dean, H. T. and Elvove, E.: Studies on the minimal threshold of the dental sign of chronic endemic fluorosis (Mottled enamel), Pub. Health Rep., 50 : 1719-1729, 1935.

2) Dean, H. T. and Elvove, E.: Further studies on the minimal threshold of chronic endemic dental fluorosis, Pub. Health Rep., 52: 1249-1264, 1937.

3）美灌口玄ほ加：斑状歯と飲料水中弗素量の変 動, 京大口科紀要, $1: 679-683,1959$.

4）牛尾光国 : 斑状歯（歯牙弗素症）の発現につい
ての考察, 京大口科紀要, 4(3): 99-129, 1965.

5) 久米田俊英ほか：北津㹩地方に打ける斑状断発 現に関する調查報告, 岩手医大歯誌, 1(1):2734, 1976.

6）松田和弘洁：青森県北津軽郡における斑状齿 発生地域の飲料水中化学成分について, 口腔衛 生会誌, 27(1)：8-14, 1977.

7) Dean, H. T. and McKay, F. S. : Production of mottled enamel halted by a change in common water supply, Am. J. Pub. Health, 29 : 590-596, 1939.

8）飯島洋一ほか：北津㹩地方に㧍ける斑状齿発現 に関する追跡調查(抄録), 口腔衛生会誌, $27(3)$ : $164,1977$.

9）田沢光正ほか：フッ素地区および非フッ素地区

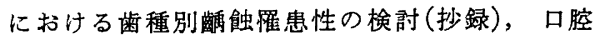
衛生会誌, $27(3): 167,1977$.

10）上田喜一ほか：給水中フッ素濃度変動に伴う歯 牙フッ素症抢よびう強䍜患状況の推移について (抄録), 口腔衛生会誌, 27(3)：161-163，1977.

11) Suttie, J. W. and Faltin, E. C. : Effect of a short period of fluoride ingestion on dental fluorosis in cattle, Am. J. Vet. Res., 32(2) : 217-222, 1971.

\begin{abstract}
The Fluctuations in Fluoride Concentration of Water Supplies in a Dental Fluorosis Area (Kitatsugaru), Kazuhiro MATSUDA*, Yoichi IIZIMA*, Mitsumasa TAZAWA*, Yoshinori TAKAESU* and Toshihide KUMETA*\%. This report describes the fluctuations in the fluoride concentration of water supplies obtained from deep wells (about 200-300 meters in depth) in Kitatsugaru area, where dental fluorosis is endemic. The fluoride contents of 11 water samples obtained monthly from each source were analyzed with a fluoride ion electrode. Of 23 deep wells, great variations were found at four sources (coefficient of variation: 22-37 percent). When the fluoride concentrations of 28 water samples, obtained daily from one of these four sources, were determined to check the effect of each sampling day, it was found that the variation of the fluoride concentration was daily and irregular. When analyzing the relationship between special tissues of a body and the fluoride content of drinking water, it is necessary to determine fluoride content at regular intervals, e.g. during a month or a year, in order to estimate adequately the mean value of fluoride content as well as to prevent errors resulting from a single fluoride determination.
\end{abstract}

